\title{
SISTEM PENGUPAHAN BURUH BONGKAR MUAT DI PELABUHAN WIRA INDAH PEKANBARU MENURUT PERSPEKTIF EKONOMI ISLAM
}

\author{
Putri Nuraini* \\ *Fakultas Agama Islam (FAI) Universitas Islam Riau (UIR) Pekanbaru \\ Jl. Kaharuddin Nasution No. 113 Perhentian Marpoyan Pekanbaru 28284 \\ e-mail: putrinuraini@fis.uir.ac.id
}

\begin{abstract}
Abstrak : Penelitian ini dilatarbelakangi oleh sistem pengupahan yang tidak terlepas dari adanya keterkaitan antara pengusaha dengan para pekerja/buruh. Buruh yang bekerja sudah tentu mengharapkan upah dari hasil kerjanya, begitu juga dengan buruh bongkat muat di Pelabuhan Wira Indah Pekanbaru yang berlokasi di Jalan Tanjung Batu Kelurahan Pesisir Kecamatan Limapuluh Kota Pekanbaru Riau. Permasalahan yang dibahas dalam penelitian ini adalah bagaimana sistem pengupahan dan perspektif Ekonomi Islam terhadap sistem pengupahan. Penelitian ini merupakan penelitian lapangan (field research). Analisa data bersifat deskriptif, setelah data yang diperlukan diperoleh, lalu data tersebut dikelompokkan dan diuraikan sesuai dengan jenisnya dan dianalisa dengan menggunakan analisis kualitatif. Hasil penelitian ini menunjukkan bahwa dalam sistem pengupahan buruh bongkar muat menggunakan sistem upah borongan perkapal. Dalam pengupahan ini tidak terdapat standarisasi yang diterapkan oleh pelabuhan. Hal ini mengakibatkan para pekerja/buruh dalam menerima upah masih dikatakan masih belum mencukupi kebutuhan hidup sehari-hari. Menurut Ekonomi Islam, sistem pengupahan ini belum memenuhi hukum syariah, karena dalam syariat Islam setiap majikan berkewajiban untuk menetapkan upah minimum/ standar upah bagi para pekerjanya agar dapat memenuhi kebutuhan hidup layak.
\end{abstract}

Kata Kunci : Buruh Bongkar Muat, Sistem Pengupahan, Ekonomi Islam 


\section{PENDAHULUAN}

Seorang yang bekerja pada suatu perusahaan mengharapkan imbalan atau balas jasa dari hasil pekerjaannya, hal ini merupakan tujuan utama dari seseorang untuk bekerja. Tuntutan mengharuskan agar setiap orang bekerja dan berusaha dalam rangka untuk memenuhi kebutuhan hidup sehari-hari, dan sudah merupakan fitrah bagi manusia untuk dapat mewujudkan segala keinginan dan kebutuhan hidupnya.

Perusahaan sudah tentu memerlukan tenaga kerja atau buruh guna menopang kelancaran dan keberhasilan usahanya. Bagi mereka yang tidak memiliki modal namun ingin meningkatkan taraf hidupnya maka mereka mencari tempat bekerja dan sebagai akibatnya antara pengusaha dan pencari kerja (buruh) timbul suatu perjanjian kerja yang dalam istilah Fiqh disebut Aqad Ijarah Al-Amal. Al-Ijarah merupakan salah satu bentuk kegiatan muamalah dalam memenuhi kebutuhan hidup manusia (Haroen, 2007).

Ekonomi Islam adalah ilmu pengetahuan sosial yang mempelajari masalah-masalah ekonomi rakyat yang diilhami oleh nilai-nilai Islam (Nasution, et al., 2007). Ekonomi Islam selain menginginkan tingkat kesejahteraan hidup yang optimum, juga sangat menitikberatkan adanya pemenuhan kebutuhan yang bersifat integratif, yang tidak hanya berhenti pada pemenuhan kebutuhan secara materi saja namun juga pemenuhan kebutuhan secara spiritualis (Jusmaliani, 2008).

Dalam ruang lingkup pelabuhan adalah penting mengetahui dan memahami pekerjaan buruh mengingat dalam pelaksanaannya di lapangan, merekalah tulang punggung dari kelancaran aktivitas bongkar muat barang yang dikirim melaui pelabuhan. Buruh adalah orang yang bekerja untuk orang lain dengan mendapatkan upah atau imbalan (Kamus Besar Bahasa Indonesia, 2008). Upah adalah uang dan sebagainya, yang dibayarkan sebagai pembalas jasa atau sebagai pembayar tenaga yang sudah dikeluarkan untuk mengerjakan sesuatu.

Sistem pengupahan merupakan kerangka bagaimana upah diatur dan ditetapkan sistem. Pengupahan di Indonesia pada umumnya didasarkan kepada tiga fungsi upah, yaitu menjamin kehidupan yang layak bagi pekerja dan keluarganya, mencerminkan imbalan atas hasil kerja seseorang, menyediakan insentif untuk mendorong peningkatan produktivitas kerja (Sumarsono, 2009).

Kebutuhan ekonomi merupakan sesuatu hal yang penting bagi para pekerja. Masalah upah ini sangat penting dan berdampak luas, upah pekerja akan berdampak pada kemampuan daya beli yang akhirnya mempengaruhi standar kehidupan pekerja dan keluarganya, bahkan masyarakat umum. Jika para pekerja tidak mendapatkan upah yang adil dan wajar, ini tidak hanya akan mempengaruhi daya beli dan taraf hidup para pekerja serta keluarganya saja. Akan tetapi, secara tidak langsung akan berpengaruh terhadap seluruh komunitasnya, sebab mereka mengkonsumsi sebagian besar produk nasional.

\section{TINJAUAN PUSTAKA}

\section{Pengertian Upah dan Dasar Hukumnya}

Dalam bahasa Arab upah disebut dengan Al-Ijarah, yang berasal dari kata Al-Ajru yang berarti Al-'Iwadhu (ganti). Dari sebab itu Ats-Tsawab (pahala) dinamai Ajru (upah). Menurut pengertian Syara', Al-Ijarah adalah suatu jenis akad untuk mengambil manfaat dengan jalan penggantian (upah) (Sabiq, 1988). Dalam Kamus Besar Bahasa Indonesia (2008) Upah adalah uang dan sebagainya yang dibayarkan sebagai pembalas jasa atau sebagai pembayar tenaga yang sudah dikeluarkan untuk mengerjakan sesuatu. 
Para ulama fiqh juga mengemukakan tentang upah, adalah sebagai berikut :

1) Ulama Hanafiah, ijarah adalah transaksi terhadap suatu manfaat dengan imbalan.

2) Ulama asy-Syafi'iyah, ijarah adalah transaksi terhadap suatu manfaat yang dituju, tertentu, bersifat mubah dan boleh dimanfaatkan dengan imbalan tertentu.

3) Ulama Malikiyah dan Hanabilah, ijarah adalah pemilikan manfaat sesuatu yang dibolehkan dalam waktu tertentu dengan suatu imbalan (Haroen, 2007).
Menurut
Dewan
Penelitian

Pengupahan Nasional, upah adalah suatu penerimaan sebagai imbalan dari pemberi kepada penerima kerja untuk suatu pekerjaan atau jasa yang telah dan akan dilakukan, berfungsi sebagai jaminan kelangsungan hidup yang layak bagi kemanusiaan dan produksi, dinyatakan atau dinilai dalam bentuk uang yang ditetapkan menurut suatu persetujuan, undang-undang dan peraturan dan dibayarkan atas dasar suatu perjanjian kerja antara pemberi dan penerima kerja (Rivai, 2009).

Dari beberapa definisi yang telah diuraikan diatas dapat dilihat berbagai redaksi dari pengertian Ijarah namun apabila dicermati dapat diambil suatu kesimpulan yang sama tentang masalah upah. Dapat dikatakan upah adalah penerimaan sebagai imbalan dalam bentuk uang atau lainnya yang dapat dinilai, adanya tunjangan untuk diri dan keluarga, adanya suatu perjanjian dan diterima menurut ketentuan waktunya.

Dalam syari'at Islam, landasan pengupahan kaum buruh atas jasa yang diberikan kepada majikannya dapat dilihat dalam :

Al-Qur'an Surat Al-Baqarah ayat 233 yang berbunyi :

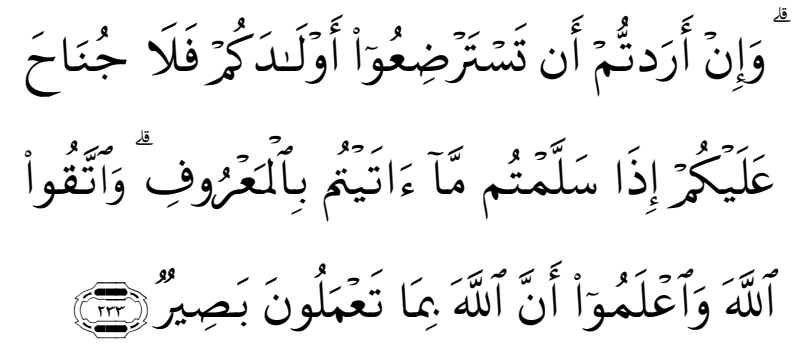

Artinya : "Dan jika kamu ingin anakmu disusukan oleh orang lain, maka tidak dosa bagimu apabila kamu memberikan pembayaran menurut yang patut. Bertaqwalah kamu kepada Allah dan ketahuilah bahwa Allah Maha Melihat apa yang kamu kerjakan".

Hadits Rasulullah SAW yang diriwayatkan oleh Ibnu Majah (1995) yang berbunyi :

$$
\text { أعطو الأجير أجره قبل أن يجفَّ عرقه }
$$

Artinya:"Berikanlah upah buruh, sebelum kering keringatnya" (HR. Ibnu Majah)

Maksud hadits diatas berikanlah upah kepada seseorang itu pada waktu berakhirnya pekerjaannya dan jangan menangguhkannya. Dengan adanya dasar hukum yang dikemukakan diatas, jelaslah bahwa Ijarah merupakan sesuatu yang dibolehkan. Dalam hal upah, memberikan upah hendaknya setelah ada ganti dan yang di upah tidak berkurang nilainya, seperti : memberi upah kepada yang menyusui, upah ini diberikan karena sebab menyusui tidak karena susunya, tetapi hal mengerjakannya. Sebagaimana orang yang menyewa rumah dan dalamnya ada sumur boleh mengambil air sumur dan nilai rumah dan sumur tidak berkurang. Tidak boleh menyewakan dengan mengurangkan nilai yang disewa, seperti menyewa kebun yang berbuah, menyewa kambing karena susunya atau diambil anaknya sebab yang demikian mengurangkan nilainya.

Dalam hukum positif juga diatur tentang pengupahan diantaranya, dalam Undang-Undang Dasar 1945 pasal 27 ayat 2 yang berbunyi : " Tiap-tiap warga Negara berhak atas pekerjaan dan 
penghidupan yang layak bagi kemanusiaan" (Kitab Undang-Undang 1945). Dengan demikian upah yang harus diterima oleh buruh atau pekerja atas jasa yang diberikan haruslah berupa upah yang wajar.

\section{Sistem Pembayaran Upah}

Menurut hukum positif penetapan upah, terdapat berbagai sistem pembayaran upah, pembayaran itu sebagai berikut :

1) Sistem upah jangka waktu;

2) Sistem upah potongan;

3) Sistem upah pemufakatan;

4) Sistem skala upah buruh;

5) Upah Indeks;

6) Sistem upah pembagian keuntungan;

7) Upah sistem Hasil (Output)

8) Upah sistem borongan (Rivai, 2009).

Sistem borongan adalah suatu cara pengupahan yang penetapan besarnya jasa didasarkan atas volume pekerjaan dan lama mengerjakannya. Upah borongan diberikan sesuai dengan kesepakatan antara pekerja dengan pihak yang memberi pekerjaan sebelum pekerjaan dimulai.

Dalam hal ini, sistem upah yang berlaku di pelabuhan Wira Indah Pekanbaru adalah sistem upah borongan perkapal, yakni pemberian upah berdasarkan kesepakatan pemberian kerja dan pekerja. Upah borongan untuk buruh jika barang-barang yang akan dibongkar atau dimuat kekapal banyak bisa mencapai Rp.12.000.000,- (dua belas juta rupiah) perkapal bahkan lebih. Upah borongan perkapal tersebut akan dibagi sebanyak buruh yang bekerja. Masingmasing buruh bongkar muat akan mendapatkan upah sebesar Rp.12.000.000/25 = Rp. 480.000,- (empat ratus delapan puluh ribu rupiah). Biasanya dalam sebulan kapal merapat kedermaga pelabuhan sebanyak 2-3 kali.

Dalam ruang lingkup pelaksanaan pembayaran upah buruh secara terperinci tentu terlebih dahulu diketahui bagaimana sistem pengupahan bagi buruh bongkar muat, dimana upah itu dibayarkan, jika tempat pembayaran upah tidak ditentukan dalam peraturan perusahaan maka pembayaran upah dilakukan ditempat buruh biasa bekerja atau dikantor perusahaan, begitu juga dengan jangka waktu pembayaran upahnya.

Upah yang diterima oleh pekerja/ buruh seharusnya wajar dan dapat memenuhi kebutuhan secara minimal, misalnya kebutuhan makan, minum, pakaian dan perumahan. Oleh karena itu, dalam menetapkan upah setiap perusahaan harus mengupayakan sedemikian rupa sehingga upah yang terendah yang diberikan dapat memenuhi kebutuhan minimal. Sistem pengupahan buruh bongkar muat di Pelabuhan Wira Indah tidak terdapat standarisasi upah yang diterapkan. Buruh/ pekerja mengharapkan adanya standarisasi upah yang diberlakukan oleh pihak pelabuhan. Hal ini banyak dikeluhkan oleh para buruh sebab tidak adanya kepastian berapa upah minimal atau standar upah yang ditetapkan, kemudian upah buruh tersebut belum bisa sepenuhnya mencukupi kebutuhan hidup.

\section{Macam-Macam Upah}

Pembagian ijarah biasanya dilakukan dengan memperhatikan objek ijarah tersebut. Ditinjau dari segi objeknya, akad ijarah dibagi ulama fiqih menjadi dua macam, yaitu :

1) Ijarah yang bersifat manfaat, disebut juga sewa-menyewa.

2) Ijarah yang bersifat pekerjaan, disebut juga upah-mengupah.

Ijarah yang bersifat manfaat, bisa dianggap terlaksana dengan penyerahan barang yang disewa kepada penyewa untuk dimanfaatkan, seperti sewamenyewa rumah, toko, kendaraan, pakaian, perhiasan dan sebagainya. Apabila manfaat itu merupakan manfaat yang dibolehkan syara' untuk dipergunakan, maka ulama fiqih sepakat menyatakan boleh dijadikan objek sewamenyewa. 
Ijarah yang bersifat pekerjaan adalah dengan cara memperkerjakan seseorang untuk melakukan suatu pekerjaan. Ijarah seperti ini menurut ulama fiqih hukumnya boleh apabila pekerjaan itu jelas, seperti buruh bangunan, tukang jahit, buruh pabrik dan tukang sepatu. Ijarah seperti ini ada yang bersifat pribadi, seperti menggaji seorang pembantu rumah tangga, dan ada yang bersifat serikat, yaitu seseorang atau sekelompok orang yang menjual jasanya untuk kepentingan orang banyak (seperti tukang sepatu, buruh pabrik dan tukang jahit). Kedua bentuk ijarah terhadap pekerjaan ini menurut ulama fiqih hukumnya boleh (Ensiklopedi Hukum Islam, 2006). Kemudian fuqaha telah bersepakat tentang kebolehan menyewakan rumah, kendaraan (hewan) dan pekerjaan orang (jasa) yang tidak dilarang (mubah) (Rusyd, 2002).

\section{METODE}

Penelitian ini merupakan penelitian lapangan (field research). Analisa data bersifat deskriptif, setelah data yang diperlukan diperoleh, lalu data tersebut dikelompokkan dan diuraikan sesuai dengan jenisnya dan dianalisa dengan menggunakan analisis kualitatif. Penelitian deskriptif menurut Sugiyono (2013) adalah penelitian yang dilakukan untuk menggambarkan sesuatu yang telah berlangsung pada saat riset dilakukan atau menggambarkan fenomena-fenomena yang terjadi disekitar objek penelitian untuk mengetahui nilai variabel mandiri.

Penelitian ini dilakukan pada Pelabuhan Wira Indah di Jalan Tanjung Batu Kelurahan Pesisir Kecamatan Limapuluh Kota Pekanbaru Riau. Adapun alasan penulis memilih lokasi penelitian ini adalah karena pelabuhan ini merupakan salah satu pusat kegiatan bongkar muat barang dimana para buruh bekerja sebagai tulang punggung dari kelancaran pengiriman barang. Dari pekerjaan tersebut apakah mampu meningkatkan ekonomi mereka serta membawa pelaksanaan kerja yang lebih efektif.

Populasi dan Sampel pada penelitian ini diartikan sebagai wilayah generalisasi yang terdiri atas; objek/subjek yang mempunyai kulaitas dan karakteristik tertentu yang ditetapkan oleh peneliti untuk dipelajari dan kemudian ditarik kesimpulan (Sugiyono, 2013). Populasi dalam penelitian ini adalah seluruh buruh (bongkar muat) tetap yang bekerja di Pelabuhan Wira Indah Pekanbaru berjumlah 25 orang. Sedangkan sampel diartikan sebagai bagian dari jumlah dan karakteristik yang dimiliki oleh populasi tersebut (Sugiyono, 2013). Oleh karena populasi dalam penelitian ini terjangkau, maka seluruh populasi akan dijadikan sampel dengan menggunakan teknik total sampling.

Dalam rangka untuk memperoleh data dan informasi, penulis menggunakan beberapa metode pengumpulan data, antara lain :

1. Data Primer

Data primer sumber data penelitian yang diperoleh langsung dari buruh yang bekerja di Pelabuhan Wira Indah Pekanbaru. Dalam penelitian ini yang termasuk kedalam data primer adalah data yang diperoleh melalui observasi atau pengamatan langsung, wawancara dan dokumentasi dengan pihak yang terkait di Pelabuhan Wira Indah Pekanbaru (perusahaan) yang menangani bagian yang berkaitan dengan masalah yang diteliti.

a. Wawancara (interview)

Menurut Sugiyono

wawancara digunakan sebagai teknik pegumpulan data apabila peneliti ingin melakukan studi pendahuluan untuk menentukan permasalahan yang harus diteliti, dan juga untuk mengetahui hal-hal dari responden yang lebih mendalam. Wawancara dalam penelitian ini adalah melakukan Tanya Jawab secara langsung kepada responden. 
b. Angket

Angket menurut Istijanto (2005) adalah suatu daftar pertanyaan yang digunakan periset untuk memperoleh data secara langsung dari sumber melalui proses komunikasi dengan mengajukan pertanyaan. Angket dalam penelitian ini yaitu dengan mengajukan pertanyaan secara tertulis kepada responden.

c. Observasi

Menurut Sutrisno Hadi (2001) observasi bisa diartikan sebagai "Pengamatan dan pencatatan secara sistematis atas fenomenafenomena yang diteliti". Observasi dalam penelitian ini adalah dengan mengamati secara langsung ke lokasi penelitian digunakan sebagai datapenjelas terhadap hasil wawancara dan angket.

d. Dokumentasi

Adapund dokumentasi penelitian ini yaitu berupa foto-foto mengenai kegiatan yang ada di tempat penelitian.

2. Data Sekuder

Adapun sumber data sekunder yang diperlukan dalam penelitian ini adalah diantaranya dokumen pemberian informan yang berkaitan dengan penelitian, laporan-laporan, sumber pustaka, karya tulis yang berhubungan dengan penelitian dan penelitianpenelitian terdahulu.

\section{HASIL}

\section{Aktivitas Buruh Bongkar Muat di Pelabuhan}

Pelabuhan dalam aktivitasnya mempunyai peran penting dan strategis untuk pertumbuhan industri dan perdagangan serta merupakan segmen usaha yang dapat memberikan kontribusi bagi pembangunan nasional. Hal ini membawa konsekuensi terhadap pengelolaan segmen usaha pelabuhan tersebut agar pengoperasiannya dapat dilakukan secara efektif, efisien dan profesional sehingga pelayanan pelabuhan menjadi lancar, aman, dan cepat dengan biaya yang terjangkau.

Pelabuhan Wira Indah yang letaknya tidak terlalu jauh dengan perkotaan merupakan salah satu faktor yang menjadikan pelabuhan ini cukup dikenal orang. Pelabuhan ini sebenarnya tidak terlalu luas, tetapi mempunyai fasilitas sarana dan prasarana yang memadai untuk aktivitas bongkar muat.

Adapun sarana-sarana fisik yang terdapat di Pelabuhan Wira Indah adalah sebagai berikut :

1) Kantor;

2) Gudang Barang;

3) Lapangan untuk bongkar muat;

4) Kantin;

5) Tempat Parkir;

6) Pos Jaga.

Sebagaimana layaknya sebuah pelabuhan yang berfungsi sebagai tempat transit barang-barang, maka di pelabuhan ini telah dibangun prasarana penunjang aktivitas kerja buruh. Mengenai rincian prasarana yang terdapat di Pelabuhan Wira Indah dapat dilihat pada tabel dibawah ini: 
Tabel. 1

Prasarana Pelabuhan Wira Indah

\begin{tabular}{|c|l|c|c|c|}
\hline No. & \multicolumn{1}{|c|}{ Uraian } & Luas $\left(\mathrm{m}^{2}\right)$ & Kapasitas & Konstruksi \\
\hline 1 & Gedung Kantor & 56 & 5 orang & Permanen \\
2 & Lapangan Terbuka & 1200 & 15 unit Truk & Timbunan Batu Pecah \\
3 & Lapangan Parkir & 1200 & 15 unit Truk & Timbunan Batu Pecah \\
4 & Gudang I & 95 & 10 Colt Diesel & Semi Permanen \\
5 & Gudang II & 72 & 8 Colt Diesel & Semi Permanen \\
\hline
\end{tabular}

Sumber Data : Pelabuhan Wira Indah Pekanbaru, 2013

Adapun keberadaan buruh bongkar muat di Pelabuhan Wira Indah diawali sejak berdirinya pelabuhan yaitu sekitar tahun 1992 pilihan menjadi buruh pelabuhan merupakan alternatif kerja yang tidak begitu mengandalkan skill atau keahlian tertentu, dengan demikian wajar tingkat mereka kebanyakan rendah. Tingkat pendidikan para buruh kebanyakan pada jenjang tamatan SD, dengan variasi yang berbeda. Buruh yang bekerja merupakan buruh kasar yang menggunakan tenaganya karena tidak memiliki keahlian dibidang tertentu.

Adapun barang-barang yang dikirim keluar daerah Pekanbaru, dalam kegiatan bongkar muat barang di pelabuhan ini adalah barang-barang berupa :

1) Elektronik;

2) Unilever;
3) Sembako;

4) Kendaraan bermotor;

5) dan lain sebagainya;

Barang-barang yang masuk dan keluar di kota Pekanbaru melalui Pelabuhan Wira Indah ini bukan hanya untuk masyarakat kota Pekanbaru saja, akan tetapi juga untuk memenuhi kebutuhan daerah lain di luar kota Pekanbaru, diantaranya daerah Kepulauan Riau seperti Tanjung Balai Karimun, Tanjung Pinang, Tanjunga Batu dan Batam. Tabel dibawah ini akan menjelaskan daftar nama-nama kapal yang terdaftar di Pelabuhan Wira Indah Kecamatan Limapuluh Pekanbaru. Hal ini dapat dilihat pada tabel 2 dibawah ini :

Tabel. 2

Nama-nama Kapal Yang Terdaftar di Pelabuhan Wira Indah Pekanbaru

\begin{tabular}{|c|c|c|c|}
\hline No. & Nama Kapal & GT & \multicolumn{1}{c|}{ Trayek } \\
\hline 1 & Wira Indah & 300 & $\begin{array}{l}\text { Pekanbaru - Batam - } \\
\text { Tanjung Balai Karimun }\end{array}$ \\
\hline 2 & Wira Indah 3 & 300 & $\begin{array}{l}\text { Pekanbaru - Tanjung Batu - } \\
\text { Tanjung Pinang }\end{array}$ \\
\hline 3 & Wira Indah 9 & 300 & $\begin{array}{l}\text { Pekanbaru - Tanjung Batu - } \\
\text { Tanjung Pinang }\end{array}$ \\
\hline
\end{tabular}

Sumber Data : Pelabuhan Wira Indah Pekanbaru, 2013

Adapun mengenai kegiatan operasional kapal yang berangkat serta kapasitas bongkar muat barang terhitung mulai tahun 2008 hingga tahun 2012 dapat dilihat pada tabel 3 dibawah ini : 
Tabel. 3

Kegiatan Operasional dan Kapasitas Bongkar Muat

Pelabuhan Wira Indah Tahun 2008-2012

\begin{tabular}{|c|c|c|c|c|}
\hline No. & Tahun & Jumlah Kapal (unit) & $\begin{array}{c}\text { Barang } \\
\text { (ton) }\end{array}$ & $\begin{array}{c}\text { Persentase } \\
\text { (\%) }\end{array}$ \\
\hline 1 & 2008 & 75 & 22.350 & $20.08 \%$ \\
2 & 2009 & 73 & 21.750 & $19.54 \%$ \\
3 & 2010 & 78 & 23.400 & $21.02 \%$ \\
4 & 2011 & 70 & 21.000 & $18.87 \%$ \\
5 & 2012 & 76 & 22.800 & $20.49 \%$ \\
\hline \multicolumn{2}{|c|}{} \\
\hline
\end{tabular}

Sumber : Data Olahan, 2013

Aktivitas bongkar muat barang di Pelabuhan Wira Indah ini merupakan kegiatan bongkar muat barang dari dan ke kapal, yang terdiri dari beberapa tahapan diantaranya tahap persiapan, tahap muatan, tahap pengangkutan, tahap pembongkaran, dan tahap penyelesaian.

\section{Sistem Pengupahan Buruh Bongkar Muat di Pelabuhan Wira Indah Pekanbaru}

Pelabuhan Wira Indah merupakan salah satu pelabuhan pelayaran kelautan, bergerak dibidang ekspedisi angkutan barang antar pulau dan pelabuhan yang melayani jasa bongkar muat barang dan pengiriman barang antar pulau. Fungsi pelabuhan ini cukup penting bagi kelancaran arus barang ke dan dari Pekanbaru. Melalui pelabuhan inilah kebanyakan arus barang dari Pekanbaru maupun luar Pekanbaru dikirim. Semua ini tentunya tidak terlepas dari andil para buruh bongkar muat yang bekerja sebagai tulang punggung dari kelancaran pengiriman barang tersebut. Adapun

Sistem pengupahan buruh bongkar muat di Pelabuhan Wira Indah Pekanbaru adalah menggunakan sistem upah borongan perkapal. Sistem upah borongan per kapal dengan cara menghitung banyaknya barang yang dimuat per kapal. Upah borongan per kapal sebesar Rp12.000.000,- (Dua belas juta rupiah).

Dalam menghitung besar kecilnya upah yang harus dikeluarkan berdasarkan pada perhitungan banyaknya barang yang diborong per kapal tanpa adanya standarisasi upah yang diterima oleh buruh. Jangka waktu pembayaran upah dilaksanakan sebulan sekali kemudian upah dibagikan langsung oleh bendahara pelabuhan. Upah yang diterima oleh pekerja/ buruh seharusnya wajar dan dapat memenuhi kebutuhan secara minimal, misalnya kebutuhan makan, minum, pakaian dan perumahan.

Jawaban responden terhadap sistem pengupahan dapat dilihat dalam Tabel 4 dibawah ini :

Tabel. 4

Tanggapan Responden Tentang Sistem Pengupahan Buruh Bongkar Muat di Pelabuhan Wira Indah Pekanbaru

\begin{tabular}{|c|l|c|c|}
\hline No & Alternatif Jawaban & Jumlah Responden & Persentase (\%) \\
\hline 1 & Wajar & 13 & $52 \%$ \\
2 & Tidak Wajar & 10 & $40 \%$ \\
3 & Sangat Tidak Wajar & 2 & $8 \%$ \\
\hline \multicolumn{2}{r|}{ Jumlah } & 25 & $100 \%$ \\
\hline
\end{tabular}

Sumber : Data Olahan, 2013 
Berdasarkan hasil angket pada table 4 tersebut, responden yang menyatakan tidak wajar dengan pemahaman bahwa tidak adanya standarisasi dalam penentuan upah walaupun upah yang diterima disesuaikan dengan jumlah barang yang dibongkar/ dimuat. Apabila barang yang dibongkar dan dimuat ke kapal banyak maka banyak pulalah upah yang diterima oleh para buruh dan sebaliknya. Hal ini banyak dikeluhkan oleh para buruh sebab tidak adanya kepastian berapa upah minimal atau standar upah yang ditetapkan, kemudian upah buruh tersebut belum bisa sepenuhnya mencukupi kebutuhan hidup terutama bagi buruh yang telah berkeluarga.

Karena upah merupakan hak yang diterima oleh setiap pekerja, maka upah yang diterima haruslah wajar sehingga dapat memenuhi kebutuhan hidup seharihari tanpa harus dicurangi oleh pihak pelabuhan. Untuk mengetahui pendapat responden tentang upah yang diterimanya apakah sudah mencukupi untuk kebutuhan hidup sehari-hari dapat dilihat dari tebel 5 dibawah ini :

Tabel. 5

Tanggapan Responden Tentang Upah Yang Diterima

\begin{tabular}{|c|l|c|c|}
\hline No & Alternatif Jawaban & Jumlah Responden & Persentase (\%) \\
\hline 1 & Mencukupi & 8 & $32 \%$ \\
2 & Pas & 15 & $60 \%$ \\
3 & Tidak Mencukupi & 2 & $8 \%$ \\
\hline \multicolumn{2}{|c|}{ Jumlah } & 25 & $100 \%$ \\
\hline
\end{tabular}

Sumber : Data Olahan, 2013

Seperti yang dapat dilihat dari tebel 5 tersebut, tanggapan responden tentang besarnya upah yang diterima umumnya menyatakan pas yaitu berjumlah 15 orang atau $60 \%$, hanya 8 orang atau $32 \%$ yang menyatakan mencukupi dan 2 orang atau 8\% menyatakan tidak mencukupi. Dengan demikian dapat disimpulkan bahwa upah yang diterima buruh bongkar muat di Pelabuhan Wira Indah Pekanbaru masih terbilang kurang, belum mencukupi kebutuhan hidup sehari-hari, hal ini dapat dilihat dari persentase jawaban responden sebesar $60 \%$ yang menyatakan kurang.

Berdasarkan hasil angket dan wawancara, dapat dianalisa dalam menggunakan sistem upah borongan perkapal, dari segi kewajaran dalam sistem pengupahan buruh bongkar muat ini penulis menilai bahwa ada yang terlaksanan dengan baik/ wajar dan ada juga yang terlaksana kurang baik/ kurang wajar. Dapat digambarkan dari hasil angket pada Tabel 4 tanggapan responden yang menilai wajar berjumlah 13 orang. Namun terdapat beberapa responden yang menyatakan tidak wajar berjumlah 10 orang atau sebesar $40 \%$, hal ini terjadi karena menurut pemahaman mereka tidak adanya standarisasi dalam penentuan upah ini mengakibatkan belum atau kurang wajarnya upah yang mereka terima. Karena upah merupakan hak yang diterima oleh setiap pekerja, maka pihak pelabuhan harus menerapkan standarisasi upah, agar upah yang didapat oleh pekerja/ buruh mampu mencukupi kebutuhan hidup sehari-hari.

Sejalan dengan permasalahan dalam penelitian ini bahwa dalam sistem pengupahan buruh bongkar muat di Pelabuhan Wira Indah, para buruh/ pekerja mengharapkan adanya standarisasi upah yang diberlakukan 
oleh pihak pelabuhan. Hal ini banyak dikeluhkan oleh para buruh sebab tidak adanya kepastian berapa upah minimal atau standar upah yang ditetapkan, kemudian upah buruh tersebut belum bisa sepenuhnya mencukupi kebutuhan hidup. Dapat dilihat dari Tabel 5 tanggapan responden tentang besarnya upah yang diterima umumnya menyatakan kurang yaitu berjumlah 15 orang atau $60 \%$, hanya 8 orang atau $32 \%$ yang menyatakan mencukupi.

Upah borongan perkapal seharusnya dibagi kepada jumlah buruh yang bekerja saja sebanyak 25 orang, akan tetapi dalam pelaksanaannya upah tersebut dibagi juga untuk gudang, pelabuhan, dan mandor yang mana pembagiannya berjumlah 31 orang. Maka untuk masing-masing buruh bongkar muat akan mendapatkan upah sebesar Rp.12.000.000/31 = Rp. 387.096,- (tiga ratus delapan puluh tujuh ribu sembilan puluh enam rupiah). Biasanya buruh dapat menyelesaikan pekerjaannya dalam waktu 3 hari. Upah yang diterima tersebut belum sepenuhnya memenuhi kebutuhan artinya masih terbilang kurang.

Apabila barang yang dibongkar dan dimuat kekapal banyak maka banyak pula upah yang diterima oleh para buruh dan sebaliknya. Hal ini banyak dikeluhkan oleh para buruh sebab tidak adanya kepastian berapa upah minimal atau standar upah yang ditetapkan, kemudian upah buruh tersebut belum bisa sepenuhnya mencukupi kebutuhan hidup terutama bagi buruh yang telah berkeluarga. Untuk mengetahui apakah pernah mengajukan usul kenaikan upah terhadap pihak pelabuhan, karena perbaikan upah merupakan harapan setiap pekerja/ buruh agar dapat memenuhi kebutuhan hidupnya, hal ini dapat dilihat pada tabel 6 dibawah ini :

Tabel. 6

Tanggapan Responden Tentang Usul Yang Diajukan Kepada Pelabuhan Untuk Kenaikan Upah

\begin{tabular}{|c|l|c|c|}
\hline No & Alternatif Jawaban & Jumlah Responden & Persentase (\%) \\
\hline 1 & Penah & 14 & $56 \%$ \\
2 & Tidak Pernah & 8 & $32 \%$ \\
3 & Tidak Tahu & 3 & $12 \%$ \\
\hline \multicolumn{2}{|c|}{ Jumlah } & 25 & $100 \%$ \\
\hline
\end{tabular}

Sumber : Data Olahan, 2013

Dari tabel di atas dapat diketahui apakah responden pernah mengajukan usulan kepada pihak pelabuhan mengenai kenaikan upah, dari 25 responden yang menyatakan pernah berjumlah 14 orang atau $56 \%$, yang menyatakan tidak pernah berjumlah 8 orang atau $32 \%$ dan yang menyatakan tidak tahu berjumlah 3 orang atau $12 \%$. Berdasarkan jawaban responden diatas, terlihat bahwa sebagian buruh bongkar muat pernah mengajukan usul untuk kenaikan upah kepada pihak Pelabuhan Wira Indah Pekanbaru, hanya saja belum ada tanggapan dari pihak pelabuhan.

Disisi lain permintaan buruh terhadap kenaikan upah yang sesuai dengan kebutuhan hidup sehari-hari merupakan hak-hak dari para buruh karena upah yang mereka terima masih terbilang pas atau belum mencukupi kebutuhan minimum para pekerja/ buruh. 
Tinjauan Ekonomi Islam Terhadap Sistem Pengupahan Buruh

Makna Keadilan dalam Pengupahan. Adil dapat bermakna jelas dan transparan yang dapat dijamin dengan adanya kejelasan akad (perjanjian) serta komitmen untuk memenuhinya dari para pihak yaitu pekerja dan pengusaha. Organisasi yang menerapkan prinsip keadilan dalam pengupahan mencerminkan organisasi yang dipimpin oleh orang-orang bertaqwa (Rivai, 2009). Konsep adil ini merupakan ciri-ciri organisasi yang bertaqwa.

Firman Allah SWT dalam Q.S AlMaidah ayat 8 yang berbunyi :
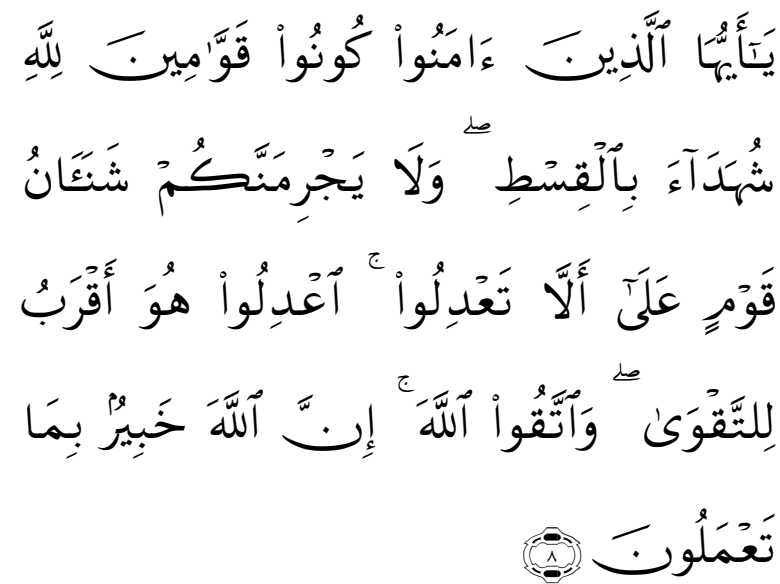

Artinya:"Hai orang-orang yang beriman hendaklah kamu jadi orang-orang yang selalu menegakkan (kebenaran) karena Allah menjadi saksi dengan adil, dan janganlah sekali-kali kebencianmu terhadap sesuatu kaum, mendorong kamu untuk berlaku tidak adil. Berlaku adillah, karena adil itu lebih dekat kepada takwa.Dan bertakwalah kepada Allah, sesungguhnya Allah Maha Mengetahui apa yang kamu kerjakan".

Ayat diatas menegaskan bahwa prinsip utama keadilan terletak pada kejelasan akad (transaksi) dan komitmen melakukannya. Akad dalam perburuhan adalah akad yang terjadi antara pekerja dengan pengusaha. Artinya, sebelum pekerja dipekerjakan, harus jelas dahulu bagaimana upah yang akan diterima oleh pekerja.

Disamping itu adil dapat bermakna proporsional, hal ini sebagaimana tersirat dalam ayat berikut yang menegaskan bahwa pekerjaan seseorang akan dibalas menurut berat ringan pekerjaannya, karena Islam sangat menghargai keahlian dan pengalaman.

Makna Layak dalam Pengupahan. Layak bermakna cukup pangan, sandang dan papan. Hal ini berarti upah harus mencukupi kebutuhan minimum dari ketiga kebutuhan yang merupakan kebutuhan dasar. Jika ditinjau dari hadits yang diriwayatkan oleh Abu Dzar bahwa Rasulullah SAW bersabda :

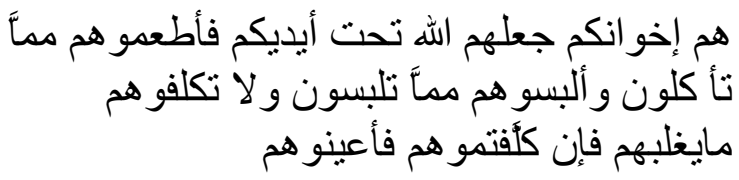

Artinya : "Mereka (para budak dan pelayanmu) adalah saudaramu, Allah menempatkan mereka dibawah asuhanmu, sehingga barangsiapa mempunyai saudara dibawah asuhannya maka harus diberinya makan seperti apa yang dimakannya (sendiri) dan memberi pakaian seperti apa yang dipakainya (sendiri), dan tidak membebankan kepada mereka dengan tugas yang sangat berat, dan jika kamu membebankannya dengan tugas seperti itu, maka hendaklah membantu mereka (mengerjakannya)" (HR. Muslim).

Hadits diatas menjelaskan bahwa kelayakan upah yang diterima oleh pekerja dilihat dari 3 aspek yaitu : pangan (makanan), sandang (pakaian) dan papan (tempat tinggal). Hadits tersebut juga menetapkan bahwa : pertama, majikan dan pekerja seharusnya saling menganggap saudara seiman dan bukan sebagai tuan dan budak. Kedua, bahwa majikan seharusnya berada pada tingkat yang sama dengan pekerjanya, paling tidak dalam soal kebutuhan mendasar. Ketiga, bahwa seorang pekerja tidak boleh dibebani dengan tugas yang terlalu berat atau sulit, yaitu tugas yang melampaui kemampuannya atau mungkin membuatnya berada dalam kesulitan yang besar dalam mengerjakannya (Afzalurrahman, 1997). 
Layak juga bermakna sesuai dengan pasaran. Hal ini dapat dilihat pada makna yang tersirat dalam Q.S As-Syu'ara ayat 183 yang berbunyi :

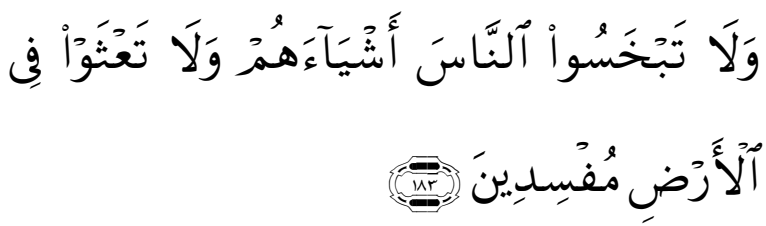

Artinya : "Dan janganlah kamu merugikan manusia dengan mengurangi hak-haknya dan janganlah kamu merajalela di muka bumi membuat kerusakan".

Ayat diatas bermakna bahwa janganlah seseorang merugikan orang lain dengan cara mengurangi hak-hak yang seharusnya di perolehnya. Dalam pengertian yang lebih jauh, hak-hak dalam upah bermakna bahwa janganlah membayar upah seseorang jauh dibawah upah yang biasanya diberikan.Dengan demikian hubungan antara pengusaha sebagai majikan dengan pekerja bukan hanya sebatas hubungan pekerjaan formal saja melainkan pekerja merupakan bagian dari keluarga pengusaha.

Islam menawarkan solusi yang sangat tepat, baik mengenai masalah upah maupun masalah perlindungan terhadap kepentingan-kepentingan pekerja maupun majikan.Para buruh mendapatkan upah yang layak tanpa melanggar hak-hak majikannya yang sah. Majikan tidak diperbolehkan berlaku sewenang-wenang terhadap kelompok pekerja dengan menghilangkan bagian hak pekerjanya yang sah, sementara para pekerja itu juga tidak diberi seluruh dividen nasional sehingga mengurangi hak yang sah dari majikannya. Upah ditetapkan dengan suatu cara yang paling layak tanpa tekanan yang tidak pantas terhadap pihak manapun. Masing-masing pihak memperoleh bagian yang sah dari produk bersamanya tanpa bersikap dzalim terhadap yang lain (Afzalurrahman, 1997).

Tidak adanya standarisasi dalam penentuan upah mengakibatkan belum atau kurang wajarnya upah yang mereka terima.Karena upah merupakan hak yang diterima oleh setiap pekerja, maka pihak pelabuhan harus menerapkan standarisasi upah, agar upah yang didapat oleh pekerja/ buruh mampu mencukupi kebutuhan hidup sehari-hari.

Para pekerja di pelabuhan merupakan buruh bongkar yang bekerja biasanya dari pagi hingga sore. Buruh yang bekerja merupakan buruh kasar yang menggunakan tenaganya karena tidak memiliki keahlian dibidang tertentu.Jadwal kerja para buruh pelabuhan sangat tergantung pada kapal yang memuat barang tersebut. Apabila barang-barang yang akan dikirim masuk ke pelabuhan dan kapal telah merapat ke dermaga maka para buruh mulai bekerja baik siang maupun malam. Dari pekerjaan inilah mereka mendapatkan gaji/upah tergantung banyak atau tidaknya barang yang dimuat kekapal.

Dalam ruang lingkup pelabuhan adalah penting mengetahui dan memahami pekerjaan buruh mengingat dalam pelaksanaannya di lapangan, merekalah tulang punggung dari kelancaran aktivitas bongkar muat barang yang dikirim melaui pelabuhan.

Islam menekankan masalah pengupahan yang wajar. Firman Allah SWT dalam Q.S Al-Baqarah ayat 233 :

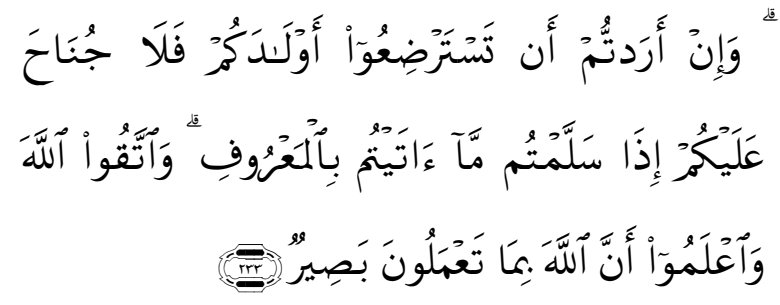

Artinya : "Dan jika kamu ingin anakmu disusukan oleh orang lain, maka tidah dosa bagimu apabila kamu memberikan pembayaran menurut yang patut.

Bertaqwalah kamu kepada Allah dan ketahuilah bahwa Allah Maha Melihat apa yang kamu kerjakan"

Adalah kewajiban setiap majikan untuk menetapkan upah minimum dan memberikan upah yang baik dan cukup bagi pekerjanya agar mereka dapat menikmati hidupnya. Majikan yang tidak 
membayar upah yang cukup pada para pekerjanya diperingatkan agar mereka memperbaiki penyimpangannya itu serta membayar upah atas apa yang telah dilakukan mereka (Afzalurrahman, 1997).

Implikasi ekonomi dari konsep upah yang adil, wajar dan transparan adalah melindungi kepentingan pekerja dan majikan serta melindungi mereka dari aksi saling mengeksploitasi. Ibnu Taimiyah menyatakan apabila seorang majikan memperkerjakan seseorang secara dzhalim dengan membayar pada tingkat upah yang rendah daripada upah yang adil, yang secara normal tidak ada seorang pun dapat menerimanya, pekerja berhak meminta upah yang adil. Sebaliknya jika seorang pekerja tidak menyelesaikan pekerjaannya, ia tidak berhak memperoleh upahnya sesuai dengan hasil pekerjaannya (Abdullah, 2010).

\section{SIMPULAN}

Sistem pengupahan buruh bongkar muat di Pelabuhan Wira Indah Pekanbaru adalah sistem upah borongan per kapal dengan menghitung banyaknya barang yang dimuat per kapal.Upah borongan per kapal sebesar Rp 12.000.000,- (Duabelas juta rupiah). Dalam menghitung besar kecilnya upah yang harus dikeluarkan berdasarkan pada perhitungan banyaknya barang yang diborong per kapal tanpa adanya standarisasi upah yang diterima oleh buruh. Jangka waktu pembayaran upah dilaksanakan sebulan sekali kemudian upah dibagikan langsung oleh bendahara pelabuhan.

Menurut Ekonomi Islam, sistem pengupahan buruh bongkar muat di Pelabuhan Wira Indah Pekanbaru dalam hal belum diterapkannya standar upah bagi buruh bongkar muat adalah belum memenuhi hukum syariah, karena dalam syariat Islam setiap majikan berkewajiban untuk menetapkan standar upah bagi para pekerjanya. Sistem pengupahan ini ditinjau dari keadilan, kewajaran dan transparansi dalam penerimaan upah adalah ada yang berjalan dengan baik dan belum ada yang berjalan dengan baik. Oleh karena prinsip keadilan, kewajaran dan transparansi merupakan konsep yang harus diutamakan dalam pengupahan menurut Islam maka dalam pelaksanaannya harus lebih ditekankan.

Agar sistem pengupahan tersebut harus tetap sesuai dengan prinsip keadilan, kewajaran dan transparansi, untuk itu diharapkan hendaknya pihak Pelabuhan Wira Indah Pekanbaru menerapkan standarisasi upah bagi buruh bongkar muat agar prinsip-prinsip tersebut dapat terlaksana dengan baik serta memberikan manfaat antara kedua belah pihak.

\section{DAFTAR RUJUKAN}

Arif, Muhammad. 2018. Analisis Rekrutmen dan Penempatan Kerja terhadap Kinerja Karyawan pada Hotel Oase. Jurnal Al-Hikmah: Vol. 15 (1): 42-63.

Afzalurrahman, Muhammad Sebagai Seorang Pedagang, (Jakarta : Yayasan Swarna Bhumy, 1997).

Boedi Abdullah, Peradaban Pemikiran Ekonomi Islam, (Bandung : Pustaka Setia, 2010).

Departemen Agama RI, Al-Qur'an dan Terjemahannya, (Semarang : PT. Karya Toha Putra, 2002).

Ensiklopedi Hukum Islam, (Jakarta : PT Ikhtiyar Baru Van Hoeve, 2006).

Ibnu Majah, Sunan Ibnu Majah, (Beirut : Dar Al Fikr, 1995).

Ibnu Rusyd, Bidayatul Mujtahid Analisa Fikih Para Mujtahid, (Jakarta : Pustaka Amani, 2002).

Istijanto, Riset Sumber Daya Manusia, Cara Praktis Mendeteksi Dimensi-Dimensi Kerja Karyawan, (Jakarta: PT. Gramedia Pustaka Utama, 2005).

Jusmaliani, Bisnis Berbasis Syariah, (Jakarta : Bumi Aksara, 2008).

Kitab Undang-Undang 1945, (Jakarta : Visi Media Utama).

Mustafa Edwin Nasution, et al., Pengantar Eksklusif Ekonomi Islam, (Jakarta : Kencana, 2007). 
Nasrun Haroen, Fiqh Muamalah, (Jakarta : Gaya Media Pratama, 2007).

Sayid Sabiq, Alih Bahasa H. Kamaluddin A.Marzuki, Fikih Sunnah, (Bandung : Alma'arif, 1988).

Sonny Sumarsono, Teori dan Kebijakan Publik Ekonomi Sumber Daya Manusia, (Yogyakarta : Graha Ilmu, 2009).

Sugiyono, Metode Penelitian Kuantitatif, Kualitatif, dan Kombinasi (Mixed Methods), (Bandung: Alfabeta, 2013).

Sutrisn Hadi. 2001. Analisis Regresi. Andi Offset. Yogyakarta.

Veithzal Rivai, Islamic Human Capital Dari Teori ke Praktik Manajemen Sumber Daya Islami, (Jakarta : Rajawali Pers, 2009).
Pusat Bahasa, Kamus Besar Bahasa Indonesia, (Jakarta : PT. Gramedia Pustaka Utama, 2008). 